\title{
Aplikasi Inshot sebagai Media Pembelajaran Jarak Jauh pada Pelajaran Bahasa Indonesia
}

\section{Inshot Application as A Remote Learning Media in Indonesian Learning}

\author{
Rima Syukhria Y. K* \& Didah Nurhamidah \\ Universitas Islam Negeri Syarif Hidayatullah, Jakarta, Jakarta, Indonesia \\ rimasyukhria@gmail.com*
}

Naskah diterima tanggal 15/12/2020, direvisi akhir tanggal 25/03/2021, disetujui tanggal 30/04/2021

\begin{abstract}
Abstrak
Penelitian ini bertujuan untuk menjelaskan penggunaan dan cara mengedit pada aplikasi edit video Inshot sebagai media pembelajaran bahasa Indonesia di sekolah pada masa pembelajaran jarak jauh. Penelitian ini menggunakan metode penelitian deskriptif kualitatif dengan cara mendeskripsikan aplikasi Inshot untuk mendapatkan penjelasan mengenai penggunaan aplikasi inshot dalam membuat media pembelajaran berbasis video pada mata pelajaran Bahasa Indonesia. Berdasarkan analisis ini didapatkan hasil bahwa aplikasi Inshot dalam editing video pembelajaran bahasa Indonesia sangat dianjurkan di unduh oleh para pendidik karna mudah dan efektif jika digunakan para pendidik.
\end{abstract}

Kata kunci: Aplikasi Inshot; Bahasa Indonesia; Media Pembelajaran.

\begin{abstract}
This study aims to explain the use and how to edit the Inshot video editing application as a medium for learning Indonesian in schools during distance learning. This study uses a qualitative descriptive research method by describing the Inshot application to get an explanation of the use of the Inshot application in making video-based learning media in Indonesian subjects. Based on this analysis, the results show that the Inshot application in editing Indonesian learning videos is highly recommended for downloading by educators because it is easy and effective when used by educators.
\end{abstract}

Keywords: Indonesian Language; Inshot Application; Learning Media. 


\section{PENDAHULUAN}

Pendidikan merupakan hal yang penting membangun peradaban sebuah bangsa. Pendidikan adalah salah satu aset untuk membangun sumber daya manusia yang berkualitas. Melalui pendidikan yang bermutu, bangsa dan negara akan menjadi lebih baik lagi kedepannya (Sulistiani et al., 2021). Maka dari itu, diperlukan model pembelajaran yang tidak hanya mampu mencerdaskan peserta didik dalam teori, tetapi juga mampu cerdas dalam praktiknya langsung. Oleh karena itu, perlu diterapkan strategi pembelajaran yang bisa menjadi sarana untuk membuka pola pikir anak dan menunjang proses pembelajaran lebih aktif dan efektif.

Para guru dituntut agar mampu menggunakan alat-alat yang dapat disediakan oleh sekolah atau lembaga pendidikan atau guru itu sendiri, dan tidak tertutup kemungkinan bahwa alat-alat tersebut sesuai dengan perkembangan dan tuntutan zaman (Arsyad, 2011). Media adalah sebuah alat yang dapat membantu apa saya yang bisa dijadikan sebagai penyalur pesan yang berguna untuk mencapai tujuan pengajaran (Djamarah \& Zaim, 2006).

Media pembelajaran dapat berupa visual, audio visual. Salah satu media audio visual ini adalah video. Maka, untuk para guru juga dituntut dapat membuat video yang menarik pada proses pembelajaran apalagi pada masa sekarang ini yang semuanya serba online termasuk proses pembelajaran. Namun dalam hal editing video, para pendidik masih kurang ahli karna rumitnya mengedit sebuah video pembelajaran atau tidak mahir teknologi pada seorang pendidik. Tapi, para pendidik tidak perlu khawatir karna terdapat salah satu aplikasi untuk mengedit video pembelajaran, yaitu aplikasi inshot yang dapat digunakan oleh para tenaga pengajar.

Pembelajaran bahasa Indonesia telah diajarkan kepada peserta didik mulai dari SD, SMP, SMA hingga Perguruan Tinggi. Dalam pembelajaran berbahasa, terdapat empat aspek kebahasaan, yaitu: keterampilan menyimak, membaca, berbicara dan menulis. Keempat aspek kebahasaan tersebut menjadi landasan seorang tenaga pengajar dalam mengajarkan pembelajaran bahasa Indonesia. Pemanfaatan TIK dalam pembelajaran bahasa Indonesia tidak lagi hanya bersifat opsional akan tetapi sudah berubah menjadi suatu keniscayaan (Kuntarto, 2017).

Pembelajaran daring dengan pola pembelajaran melalui bantuan jaringan internet akan terjadi interaksi kegiatan belajar mengajar dengan harus memanfaatkan teknologi informasi (Rachmat \& Krisnadi, 2020). Selanjutnya terdapat penelitian yang mengatakan bahwa adanya pengaruh pembelajaran online selama masa darurat covid-19 terhadap hasil belajar siswa (Subur \& Rista, 2020). Berdasarkan penelitianpenelitian tersebut penulis berasumsi bahwa pembelajaran daring dapat digunakan sebagai solusi pembelajaran pada masa pandemi yang tentunya guru harus dapat kreatif menciptakan media yang menarik.

Beberapa penelitian telah menyarankan dan menyebutkan banyak para pendidik dalam mengajar bahasa Indonesia menggunakan beberapa aplikasi e-learning seperti Edmodo, Ruangguru, Google Classroom dan masih banyak lagi (Asmuni, 2020). Namun masih belum banyak penelitian mengenai pembelajaran berbasis video. Penelitian dari Sokhibul Anshor mengatakan seiring dengan kemajuan teknologi yang dapat diterapkan pada dunia Pendidikan saat ini, khususnya pemanfaatan video dalam pembelajaran sehingga siswa tidak harus terjun langsung ke lapangan dan dapat digantikan dengan media video (Anshor et al., 2015). Pada akhirnya masih belum banyak penelitian mengenai penggunaan aplikasi edit video dalam editing media pembelajaran materi bahasa Indonesia yang sebenarnya menarik untuk dibagikan dan belajar bersama.

Di era digital pada masa pandemi ini setiap tenaga pengajar harus lebih lihai dan kreatif lagi dalam membuat media pembelajaran agar anak-anak tidak merasa bosan dan jenuh ketika belajar online (Latip, 2020). Banyak sekali media pembelajaran yang dapat digunakan oleh tenaga pengajar dalam menyampaikan materi pelajarannya atau terkait dengan pengajarannya, salah satunya yaitu dengan bentuk konten audiovisual dalam bentuk video. Salah satu aplikasi 
dalam mengedit video yang mudah ditemui dan digunakan saat ini adalah aplikasi edit video inshot.

Aplikasi edit video inshot ini sangat cocok digunakan oleh para pemula dan yang ingin mengedit video secara simple tanpa ribet. Jadi, tidak akan terganggu saat mengupload video editan dan lebih efektif (Adnin, 2016).

Berdasarkan penjelasan di atas, artikel ini disusun agar pembaca lebih memahami dan menambah pengetahuan mengenai penggunaan aplikasi edit video inshot sebagai media pembelajaran, apalagi pada masa pandemik sekarang ini.

\section{METODE PENELITIAN}

Penelitian ini penulis menggunakan pendekatan deskriptif kualitatif. Penggunaan pendekatan ini bertujuan untuk mendeskripsikan perilaku orang, peristiwa lapangan, serta kegiatan-kegiatan tertentu secara terperinci dan mendalam. Adapun yang dimaksud dengan penelitian deskriptif yaitu suatu penelitian sekedar untuk menggambarkan suatu variabel yang berkenaan dengan masalah yang diteliti tanpa mempersoalkan hubungan antar variabel (Faisal, 1989).

Diambilnya metode penelitian ini mencakup beberapa alasan. Salah satunya ialah menguraikan subjek penelitian yaitu aplikasi inshot dengan deskripsi untuk mendapatkan penjelasan mengenai penggunaan aplikasi inshot dalam membuat media pembelajaran berbasis video pada mata pelajaran Bahasa Indonesia.

\section{HASIL DAN PEMBAHASAN}

\subsection{Hasil}

Pada zaman sekarang ini, semua yang dilakukan oleh orang-orang tidak terlepas dari yang namanya handphone. Di era digital pada masa pandemi ini setiap tenaga pengajar harus lebih lihai dan kreatif lagi dalam membuat media pembelajaran agar anak-anak tidak merasa bosan dan jenuh ketika belajar online (Dinata \& Pramono, 2018).

Aplikasi edit video inshot ini sangat cocok digunakan oleh para pemula dan yang ingin mengedit video secara simple tanpa ribet. Menariknya, pada aplikasi inshot kamu bisa memotong, menyusun, dan menambahkan music pada video. Selain itu juga ada fitur input teks, emoji, dan efek yang membuat aplikasi inshot ini tambah keren.

Adapun cara menginstal aplikasi inshot di android adalah dengan mencari ikon playstore, lalu tulis di pencarian inshot.

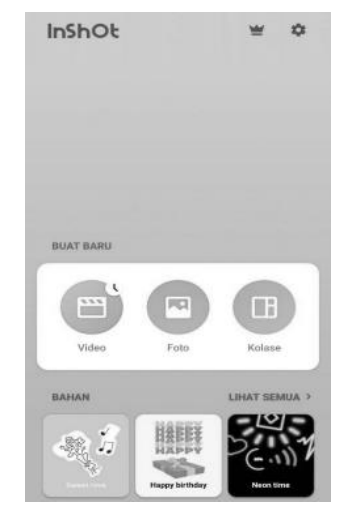

Gambar 1. Aplikasi Inshot

Daftar menu pada aplikasi inshot terdiri dari 3 bagian:

1) Video

Digunakan untuk mengedit video, memotong video, menyambungkan video, menambahkan music, menambahkan stiker, menambahkan efek dan masih banyak lagi.

2) Foto

Digunakan untuk mengedit foto, memberikan stiker, memotong atau merapikan foto, memasukkan teks, memberikan bingkai dan lain sebagainya.

3) Kolase

Digunakan untuk menggabungkan 2 atau lebih foto dengan susunan yang diinginkan editor, serta ikon lainnya hampir sama dengan menu foto akan tetapi bedanya kolase dapat menggabungkan dua atau lebih foto.

Ketiga menu aplikasi inshot di atas membuktikan bahwa aplikasi ini dapat digunakan sebagai edit video maupun foto, serta menggabungkan beberapa foto menjadi satu dan mengoperasikannya.

Video pembelajaran bahasa Indonesia hanya terdiri dari video utuh penjabaran materi yang nantinya akan di edit di aplikasi inshot agar lebih menarik dan seperti slide presentasi pada umumnya. Untuk menghasilkan hasil rekaman yang baik, 
pengguna harus memahami dengan baik Teknik menggunakan alat perekam yang digunakan. Opini mengungkapkan beberapa

Teknik dan tips menghasilkan sebuah video rekaman yang baik, yaitu sebagai berikut:

1. Gunakan perangkat kamera yang kualitas rekamannya sesuai standar yang diinginkan

2. Sediakan baterai dan memori kamera yang cukup untuk merekam video yang digunakan

3. Atur setelah kamera sesuai kebutuhan, seperti nilai frame rate dan resolusi video yang dihasilkan

4. Gunakan tripod atau monopod untuk menjaga kamera agar tidak banyak bergerak

5. Jangan banyak menggunakan zoom untuk mendapatkan kualitas gambar yang baik.

6. Perhatikan angle kamera agar hasil rekaman mampu memberikan kesan tertentu, seperti dramatis, berwibawa atau melankolis

7. Atur pencahayaan dalam proses pengambilan video dan hindari menghadap langsung pada arah datangnya cahaya

8. Jangan menggerakkan kamera secara tiba-tiba untuk mendapatkan focus yang lebih baik

9. Gunakan pergerakan kamera yang lambat untuk mendapatkan hasil rekaman yang lebih baik

10. Setelah proses merekam selesai, melakukan pengeditan hasil rekaman menggunakan aplikasi pengedit video inshot yang mudah dan praktis (Batubara \& Ariani, 2016).

Sebagai contoh, penulis akan menjelaskan cara mengedit video pembelajaran bahasa Indonesia menggunakan Aplikasi Inshot. Aplikasi Inshot adalah salah satu aplikasi yang saat ini cukup banyak diminati oleh pengguna smartphone terutama android untuk mengedit video atau foto. Aplikasi inshot ini lebih berfokus kepada pengeditan video seperti dalam penambahan lagu, efek, blur, background, stiker, penambahan teks dan masih banyak lagi.

1) Aplikasi ini dapat diunduh melalui playstore untuk android dan App Store untuk pengguna iphone. Setelah mengunduh aplikasi inshot, kemudian kita bisa masuk ke dalam aplikasinya pada menu edit video karena kita akan fokus pada editing video. Adapun tampilannya akan muncul seperti gambar sebagai berikut.

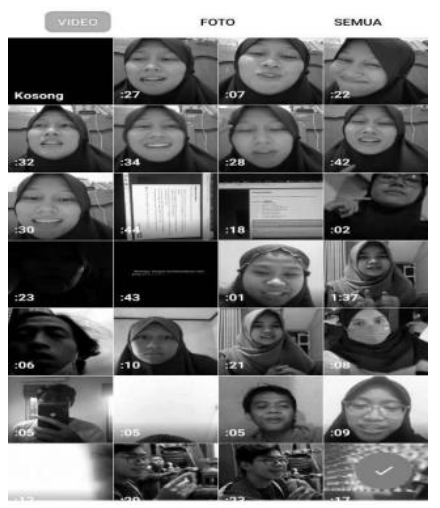

Gambar 2. Menu memilih video

2) Pada gambar di atas ketika memilih untuk mengedit video, maka akan muncul semua video yang ada di galeri handphone untuk dipilih video mana yang akan diedit dan digabungkan.

3) Ada beberapa bentuk atau ukuran video yang dapat digunakan. Dengan memilih ikon 'canvas' kita dapat untuk menentukan ukuran video kita saat disimpan nantinya, misal kurang normal video, ukuran menyesuaikan bentuk media sosial seperti facebook, Instagram, youtube, tiktok dan lainnya. Adapun tampilannya akan muncul sebagai berikut.

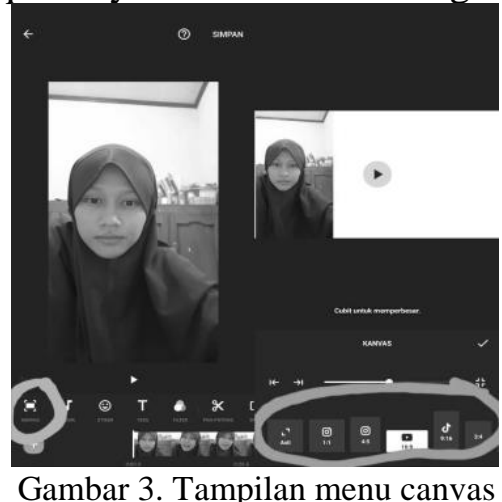

4) Pada menentukan ukuran video, kita juga bisa menggeser video kita baik ke kiri atau kanan frame menyesuaikan dalam kebutuhan edit video untuk menjelaskan materi pengajaran Bahasa Indonesia.

5) Pada penjelasan video pengajarannya, 
dapat ditambahkan teks pendukung seperti pada power point ketika seorang akan presentasi, tapi ini bentuknya dalam satu video langsung. Adapun tampilannya akan muncul sebagai berikut.

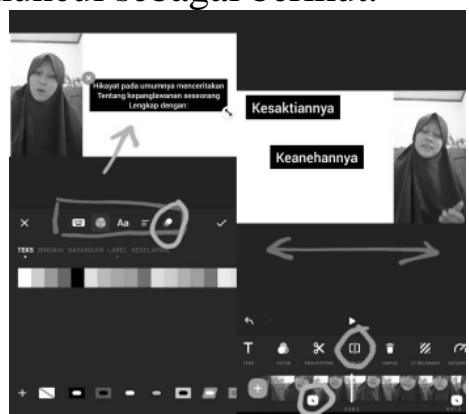

Gambar 4. Tampilan menu tambahan teks dan split

6) Pada gambar diatas, fitur penambahan teks terdapat beberapa pilihan. Seperti warna tulisannya, jenis tulisannya, posisi tulisannya dan masuk keluar teksnya untuk didapatkan teks yang menarik dan menambah daya tarik peserta didik untuk melihatnya. Merubah posisi video di frame menjadi sebelah kiri, kanan atau di tengah kita klik dahulu ikon 'split' dan muncul tanda kotak putih di tengahnya hitam bentuk pensil yang menandakan batasan antara video dan ketika di edit video yang lain tidak ikutan teredit baru setelah itu berkreasi menyesuaikan kreasi pendidik dalam mengedit video pembelajarannya.

Agar penyampaian video pembelajarannya lebih menarik. Dapat kita tambahkan lagu atau musik yang ada di galeri kita ataupun yang sudah ada di aplikasi inshotnya. Adapun tampilannya akan muncul sebagai berikut.

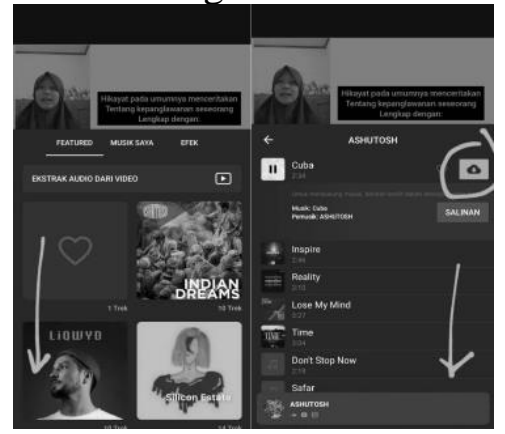

Gambar 5. Tampilan menu tambahkan music

7) Ketika menambahkan sebuah lagu atau suara ke dalam video pembelajarannya, klik ikon lagu. Lalu akan muncul tampilan seperti gambar 5. klik 'featured' jika ingin menambahkan musik bawaan dari aplikasi inshot-nya, klik 'musik saya' jika ingin menambahkan musik yang ada di memori Hp atau klik 'efek' ketika ingin juga menambahkan efek suara pada video. Namun, yang perlu diperhatikan dalam menambahkan musik yang ada di aplikasi inshot-nya adalah ketika kita ingin menambahkan sebuah musik, maka kita perlu mengunduhnya terlebih dahulu menggunakan kuota. Selain itu juga dapat menambahkan gambar atau stiker yang kita inginkan. Adapun tampilannya sebagai berikut.

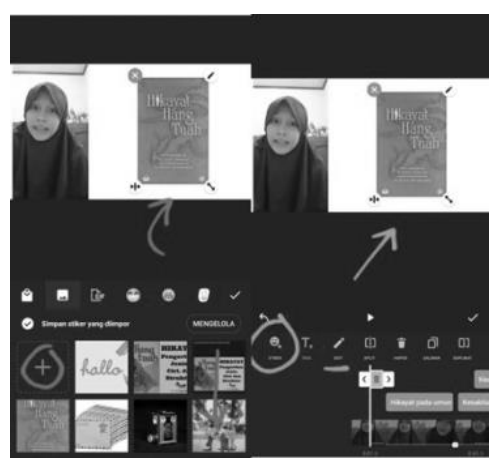

Gambar 6. Tampilkan fitur stiker

8) Ikon stiker berguna untuk menambahkan stiker-stiker yang diinginkan sesuai kebutuhan video pembelajarannya. Selain stiker, juga dapat ditambahkan menyesuaikan kebutuhan video dan ini berguna untuk menarik perhatian peserta didik dalam menonton video pembelajaran ketika guru memaparkan tentang sesuatu tapi juga memberikan gambarnya langsung seperti yang dicontohkan pada gambar 6. di atas. Tampilan stiker atau gambarnya bisa diedit letak, besar dan keluar masuk gambarnya yang mana hal ini menyesuaikan kebutuhan dan kerapian video pembelajaran. Setelah semua proses edit selesai, maka jangan lupa klik ikon 'simpan' yang terdapat pada pojok kanan atas tampilan layar Hp. Adapun tampilannya sebagai berikut. 


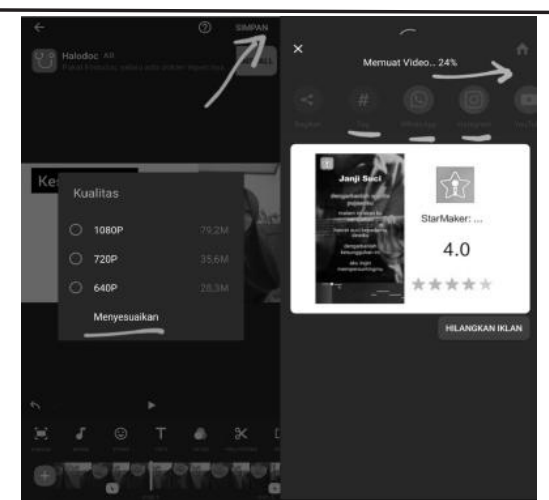

Gambar 7. Tampilkan fitur saat di klik simpan

9) Ketika klik simpan saat telah selesai mengedit video, maka akan muncul pilihan kualitas video yang diinginkan. Ada 1080p, 720p, dan paling rendah kualitas videonya 640p.

\subsection{Pembahasan}

Pandemi covid-19 menuntut para pendidik untuk melakukan perubahan-perubahan dalam pembelajaran dengan segera. perkuliahan berubah, yang awalnya tatap muka di kelas secara konvensional menjadi daring yang memerlukan perangkat teknologi. Pembelajaran daring dengan menggunakan aplikasi Zoom Meeting, Google Meet, atau yang lainnya sering kali dikeluhkan oleh peserta didik. Beberapa kendala ditemukan seperti biaya kuota internet, dan jaringan telekomunikasi yang kadang-kadang tersendat jika para pengguna terlalu banyak. Sedangkan para pengajar dituntut untuk dapat mengembangkan media dan strategi dalam pembelajaran daring. Aplikasi Inshot hadir untuk dapat membantu aktivitas pembelajran daring menjadi lebih efektif. Aplikasi Inshot merupakan aplikasi yang mudah, hemat, yang dapat mengakomodir pembelajaran.

Aplikasi Inshot seringkali digunakan di sekolah SMP Al-Amanah Tangerang Selatan. Pembelajaran Mata Kuliah Bahasa Indonesia terdapat beberapa topik yang memiliki karakter dan kebutuhan yang berbeda dengan mata pelajaran yang lain. Pembahasan mengenai teks prosedur, teks narasi, teks berita dan yang lainnya. Pembahasanpembahasan tersebut secara otomatis dalam penyampaiannya membutuhkan informasi berupa audio dan visual.

Hal tersebut sejalan dengan hasil penelitian yang dilakukan oleh Nimas Permata Putri dalam artikelnya berjudul Efektivitas
Penggunaan Aplikasi Google, In Shoot, dan Canva dalam Perkuliahan Daring/Online (Putri, n.d.). Penelitian tersebut menyatakan bahwa Aplikasi Google, In Shoot dan Canva efektif dalam tercapainya tujuan perkuliahan, mahasiswa menjadi lebih aktif di dalam perkuliahan karena adanya media yang menarik. Selanjutnya efektif dalam hal pelaksanaan perkuliahan daring yang meliputi biaya, tenaga dan waktu, karena aplikasi tersebut mudah diakses dan diunduh karena ukurannya kecil, sehingga menghemat biaya. Aplikasi tersebut juga mudah untuk dioperasikan yang tidak menguras energi.

Selanjutnya penelitian yang dilakukan oleh Hamdan Husein Batubara dengan judul Penggunaan Video Tutorial untuk Mendukung Pembelajaran Daring di Masa Pandemi Virus Corona (Batubara \& Batubara, 2020). Penelitian ini menunjukkan bahwa respon mahasiswa terhadap penggunaan video tutorial mencapai kategori baik dengan skor 4,09. Penilaian respon tersebut meliputi keuntungan relatif yang bernilai 4,29 sangat baik, kesesuaian yang bernilai 4,20 baik, kerumitan yang bernilai 3,83 baik, ketercobaan yang bernilai 3,84 baik, dan keteramatan yang bernilai 4,28 sangat baik.

\section{KESIMPULAN}

Terkait pembahasan aplikasi inshot sebagai aplikasi editing video pembelajaran Bahasa Indonesia. Dapat ditarik kesimpulan bahwa aplikasi Inshot jika digunakan sebagai aplikasi edit video bagi para pendidik sangat dianjurkan karena proses pengaturannya yang gampang dan praktis, serta gratis, tidak berbayar dan yang paling penting sangat ringan apalagi bagi pada pengguna android yang kapasitas memorinya terbatas. Penyampaian yang ringan anak-anak lebih rileks dalam mendengarkan video pembelajaran yang diputarkan serta bisa mengerti pada bagian pokok- pokok yang penting dan sekaligus menampilkan foto yang digambarkan melalui lisan. Maka aplikasi Inshot dalam editing video pembelajaran bahasa Indonesia sangat dianjurkan di unduh oleh para pendidik karna mudah dan efektif jika digunakan para pendidik. 


\section{DAFTAR PUSTAKA}

Adnin, A. R. (2016). Pengembangan Video Stop-Motion sebagai Media Pembelajaran Peserta Didik SMA/MA Kelas X Pada Materi Pokok Ikatan Kimia. Thesis. Universitas Islam Negeri Sunan Kalijaga. Retrieved from http://repository.unugha.ac.id/127/.

Anshor, S., Sugiyanta, I. G., \& Utami, R. K. S. (2015). Penggunaan Media Pembelajaran Berbasis Video terhadap Aktivitas dan Hasil Belajar Geografi. Jurnal Penelitian Geografi, 3(7).

Arsyad, A. (2011). Media pembelajaran. Jakarta: PT Raja grafindo persada.

Asmuni, A. (2020). Problematika Pembelajaran Daring di Masa Pandemi Covid-19 dan Solusi Pemecahannya. Jurnal Paedagogy, 7(4), 281-288.

Batubara, H. H., \& Ariani, D. N. (2016). Pemanfaatan Video sebagai Media Pembelajaran Matematika SD/MI. Muallimuna: Jurnal Madrasah Ibtidaiyah, 2(1), 47-66.

Batubara, H. H., \& Batubara, D. S. (2020). Penggunaan Video Tutorial Untuk Mendukung Pembelajaran Daring Di Masa Pandemi Virus Corona. Muallimuna: Jurnal Madrasah Ibtidaiyah, 5(2), 74-84.

Dinata, H., \& Pramono, R. (2018). Pemanfaatan HTML 5 Canvas dalam Proses Rendering Diagram Relasi Entitas Dengan Notasi Crow's Foot. Proceeding, Seminar Nasional Teknologi Informasi dan Multimedia 2018, 2-14. Retrieved from https://123dok.com/document/zg8711ny-pemanfaatan-rendering-diagram-entitas-dengannotasi-repository-upload.html.

Djamarah, S. B., \& Zain, A. (2006). Strategi Belajar Mengajar. Jakarta: Rineka Cipta, 46.

Faisal, S. (1989). Format-Format Penelitian Sosial: Dasar-Dasar dan Aplikasi. Jakarta: Rajawali Pers.

Kuntarto, E. (2017). Keefektifan model pembelajaran daring dalam perkuliahan bahasa Indonesia di perguruan tinggi. Indonesian Language Education and Literature, 3(1), 99-110.

Latip, A. (2020). Peran literasi teknologi informasi dan komunikasi pada pembelajaran jarak jauh di masa pandemi Covid-19. EduTeach: Jurnal Edukasi dan Teknologi Pembelajaran, 1(2), 108-116.

Putri, N. P. (n.d.). Efektivitas Penggunaan Aplikasi Google, InShot, dan Canva dalam Perkuliahan Daring/Online. Proceeding, 23.

Rachmat, A., \& Krisnadi, I. (2020). Analisis Efektifitas Pembelajaran Daring (Online) Untuk Siswa SMK Negeri 8 Kota Tangerang Pada Saat Pandemi Covid 19. Jurnal Magister Teknik Elektro Universitas Mercu Buana, 1-7.

Subur, J. M., \& Rista, N. (2020). Pengaruh Pembelajaran Online pada Masa Pandemi Covid-19 terhadap Hasil Belajar Mata Pelajaran Ilmu Pengetahuan Sosial Siswa Kelas VIII di SMP Walisongo Bekasi. JUSIE (Jurnal Sosial Dan Ilmu Ekonomi), 5(02), 156-161.

Sulistiani, S., Suminto, S., \& Suningsih, A. (2021). Pembelajaran Daring dengan Intervensi Video Pembelajaran Pada Masa Pandemi Covid 19. JURNAL E-DuMath, 7(1), 27-34.

Utami, N., Khairuddin, K., \& Mahrus, M. (2020). Perbedaan Hasil Belajar Biologi Siswa pada Penggunaan Media Video dengan Media Powerpoint Melalui Pembelajaran dalam Jaringan (Daring) di SMAN 3 Mataram Tahun Ajaran 2020/2021. Jurnal Ilmiah Profesi Pendidikan, 5(2), 96-101. 